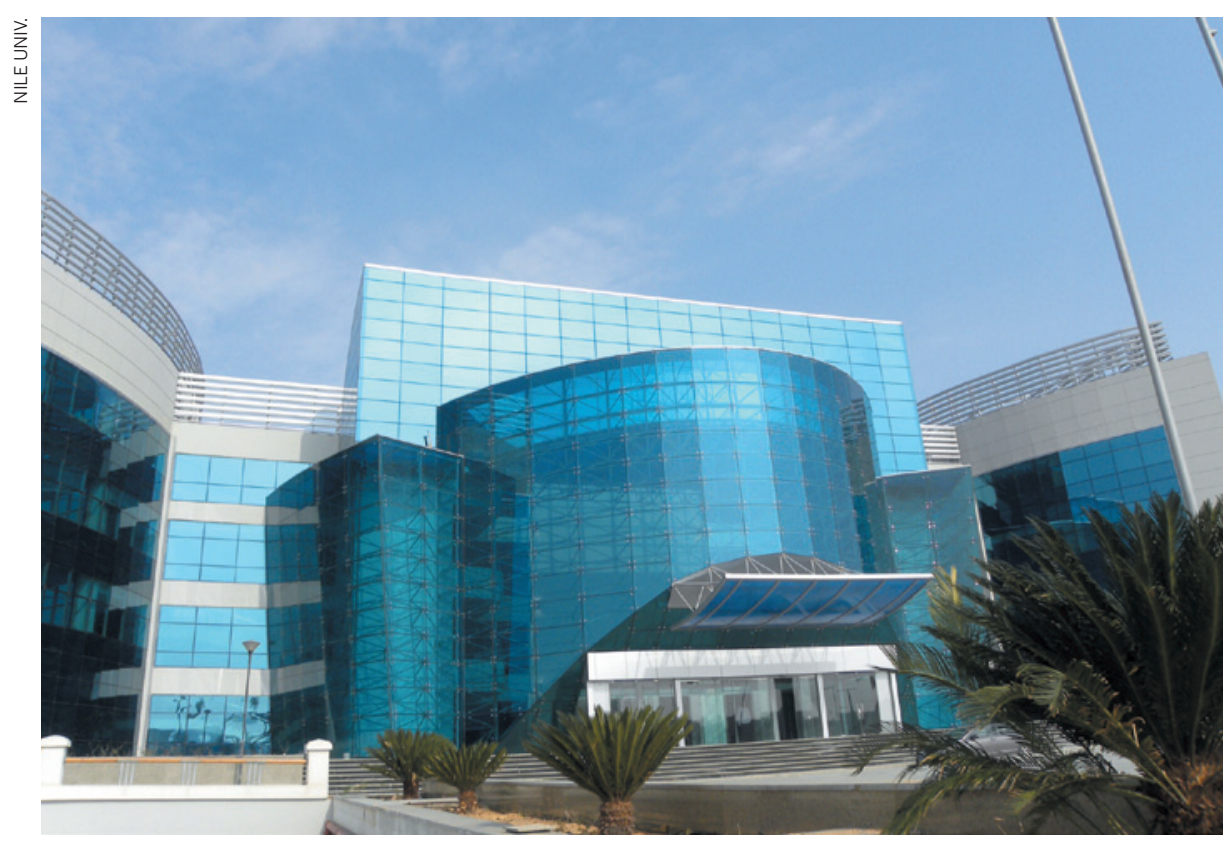

Nile University and Zewail City of Science and Technology both claim ownership of the same buildings.

HIGHER EDUCATION

\title{
Universities clash by the Nile
}

\section{Property dispute dogs Egypt's plans for a science city.}

\section{BY KATHARINE SANDERSON}

A $\mathrm{n}$ ambitious scheme to create Egypt's first science city is finally becoming a reality. Pristine glass and steel buildings are waiting for researchers and students just outside Cairo, and a grand opening is planned for September.

But a bitter property dispute is overshadowing enthusiasm for the technology park and university complex. In a quarrel that has roots in the political turmoil in Egypt in recent years, another university says that it owns some of the buildings, and that its research efforts are being thwarted.

The current occupant of the site is the Zewail City of Science and Technology, spearheaded by Ahmed Zewail, a Nobel prizewinning Egyptian chemist at the California Institute of Technology in Pasadena. Zewail first proposed the concept in 1999; a cornerstone was laid the following year, but the project was soon stalled by political instability and bureaucracy, says Zewail.

The government then allocated part of the site to Nile University, established in 2006 as Egypt's first research university by the non-profit Egyptian Foundation for Technology Education (EFTED). The institution now has about 370 students, threequarters of whom are postgraduates.

Nile University began construction work at the site, and research staff had just moved into their new labs and offices when the January 2011 revolution struck. In the aftermath of the uprising, many of the ousted regime's decisions were overruled and reversed, including its gift of land to Nile University, which tainted the university - unfairly, staff say - through its connection to the old government. In February last year, the board of EFTED signed Nile University's buildings and land over to the interim government, and staff moved out. "That was under pressure from the government, and it was illegal," says Moustafa Ghanem, vicepresident for research at Nile University and a research fellow in computing at Imperial College London.

In May 2011, the government reassigned the land and buildings to Zewail City of Science and Technology and declared the complex a National Project of Scientific Renaissance. Since then, with nowhere suitable to work, Nile University researchers have been forced to rent labs that are available for only limited hours, says Mohamed Abdel-Mottaleb, director of the university's nanotechnology programme. As a result, research is "going at a snail's pace", he adds.

Zewail had several meetings with representatives of Nile University last year to try to resolve the situation, but talks - and goodwill - have broken down. "We actually signed an agreement" to merge Nile University with the science city, says Zewail. But Nile University agreed to the deal only on the condition that it keep an independent identity, says Ghanem. Because that has not yet been guaranteed, he says, the deal is off.

The government has offered to compensate Nile University for the money it spent kitting out the buildings and labs, but without the buildings, "what would we do with that money?" asks Ghanem. Unless the situation is resolved, the university's future remains precarious, he adds. "Nile University is now surviving hand to mouth. We'll survive one more term."

Nile University students have launched a vigorous Internet campaign to save their university, using Twitter, Facebook and YouTube to gather support. Meanwhile, Zewail is pushing ahead with plans for his university, promising that curricula for undergraduate courses will be online "within weeks". "It is not just a university," he says, "we are trying to bring some pride back to Egypt, showing that it is capable of doing research and science at the world level."

A government committee heard Nile University's case earlier this month, and on 29 April decided that it would bring together the two parties to find a compromise. "We are trying to work with Dr Zewail and Nile University to reach a cordial agreement," says Abdel Tawab Othman, a member of the committee and a philosopher at Al-Azhar University, Cairo. Several options are being considered, says Othman: "Can Nile get its buildings back and Zewail get a different piece of land? Or would they agree to compensation?"

Zewail's position is that the government has legally given the buildings to his science city, and it is now too late to change that. He says that Nile University should accept the government's offer of compensation.

Ghanem hopes that Egypt's presidential elections at the end of this month will help to break the impasse. "We hope that once one of them is sworn in, we should see some action taken," he says. -

Additional reporting by Mohammed Yahia

\section{CORRECTION}

The News Feature 'Good science bad science' (Nature 484, 432-434; 2012)

wrongly located David Keith at the University of Calgary. In fact, he is at Harvard University. 